\title{
Analysis of the Economic Viability in the Implementation of the Chemical Waste Management System in Teaching and Research Laboratories
}

\author{
Beatriz Antoniassi ${ }^{1}$, Vanderlei Araújo ${ }^{1}$, Márcia Chaves ${ }^{1}$, Marcelo Telascrea $^{1}$, Mariana Kempa $^{1} \&$ Beatriz \\ Bersanetti $^{1}$ \\ ${ }^{1}$ Pró-Reitoria de Pesquisa e Pós-Graduação, Universidade do Sagrado Coração (USC), 17011-160, Bauru, São \\ Paulo, Brazil \\ Correspondence: Beatriz Antoniassi, Pró-Reitoria de Pesquisa e Pós-Graduação, Universidade do Sagrado \\ Coração (USC), 17011-160, Bauru, São Paulo, Brazil. E-mail: beatrizantoniassi@gmail.com
}

Received: November 28, 2016

Accepted: December 21, 2016 Online Published: February 3, 2017

doi:10.5539/jsd.v10n1p112

URL: http://dx.doi.org/10.5539/jsd.v10n1p112

\begin{abstract}
The prudent management of hazardous materials, from their procurement to their proper disposal, is a critical element of a departmental laboratory safety program. However, it is known that the management of chemical residues involves a high cost and few studies are carried out aiming at assisting in the implementation of this system of management mainly about educational and research institutions. This work therefore presents the economic feasibility analysis in the implementation of the chemical waste management system in laboratories of a Brazilian University. The data were obtained through a questionnaire applied to the technicians of the laboratories generating chemical residues, these being, teaching, research and clinics of the university. The economic-financial analysis has shown that the internal treatment of waste with the construction of a laboratory in the university is an unfeasible project. However, the project is feasible using the already existing structure, such as the chemistry laboratory in the idle periods. In this way, waste treatment on the university campus is feasible, in relation to the costs involved with outsourcing. However, it is necessary to ensure that the chemical standards for sewage disposal, as stipulated by the responsible bodies, are achieved.
\end{abstract}

Keywords: environmental management, hazardous waste management, treatment and disposal of waste, financial analysis

\section{Introduction}

Faced with the need to reduce costs and adapt internal processes to environmental needs, universities are pressured to modernize their management systems to provide better quality of their discards, enabling environmental technological innovations contributing to sustainable development.

Environmental Management Systems (EMS) have been one of the alternatives used by universities to achieve these goals. In general, they require the formalization of operational procedures, institute their monitoring and encourage continuous improvement, reducing the emission of waste and reducing the consumption of natural resources (water, for example).

The growing generation of solid waste in urban and university agglomerations is a serious socio-environmental problem, resulting from unsustainable patterns of production and consumption which causes environmental and public health impacts that need to be addressed (Jacobi \& Besen, 2006; Jacobi \& Besen, 2011).

Environmental management has stood out as one of the alternatives to the business and academic environment in the search for solutions to solid or liquid waste produced. The advancement of the development of sustainable consciousness passes through the education sector, like the Higher Education Institutions (HEIs). Although HEIs is responsible for the training of new professionals and new thinking minds, there are still few developed practices and few publications on the subject (Tauchen \& Brandli, 2006).

The educational institutions must put into practice what they teach and few are capable of demonstrating the path of sustainability and social responsibility. It is imperative that HEIs assume their role in technological development, preparing everyone for a more sustainable and just society (Tauchen \& Brandli, 2006; Furiam \& 
Gunther, 2006).

In this line of reasoning, organizations that seek to incorporate sustainable principles and practices, begin their awareness processes involving teachers, employees and students, in such a way that environmental issues start to permeate academic everyday diffusing decision making, planning environmental and training, ending with the practical application of their knowledge (Nolasco, Tavares, \& Bendassoli, 2006; Dionizio, 2013).

Higher Education Institutions can follow two important paths. The first highlights the environmental education and training of the student body in the development of sustainable and fair environmental practices and issues. The second involves the implementation of EMS in their university structures, as a practical application of environmental management (Cunha, 2001).

Working in this way, HEIs contribute to the opening of a broad reflection on the impacts of solid waste, allowing the university to discuss confrontations on these issues. This proposal is in line with the main themes of Rio +20 , which seeks sustainable and social development (Gouveia, 2012; Furiam \& Gunther, 2006).

In Brazil, academic activities must comply with State Law No. 12,300 of 2006, which recommends the standardization of waste discards and establishes the responsibilities of generators according to their consequences (São Paulo, 2006). Moreover, in accordance with the Environmental Crimes, Law No. 9,605 (Brazil, 1998) and the National Policy on Solid Waste, Law 12,305 (Brazil, 2010), all activity or conduct generating waste has the obligation to manage. Therefore, it is imperative that academic institutions develop management programs that correctly allocate their waste.

Although the generation of chemical waste in teaching laboratories is smaller than those produced by companies, the creation of a waste management and management system can reduce the risks that improperly stored, labeled and discarded chemicals can cause by avoiding fines for disasters (Faria, Oliveira, \& Santos, 2010; Furiam \& Gunther, 2006; Brazil, 2010).

The environmental problems at the university go through the treatment and even the disposal of waste generated. There are difficulties caused by the decentralization of higher education institutions, by the large number of experiments with various reagents (heavy metals, acids, bases, oxidants, among others), labor turnover, lack of frequency in volumes generated among others (Giloni-Lima \& Lima, 2008). These factors contribute to the difficulty of standardizing treatment and disposal.

However, since the 1970s, US universities have begun to implement waste management programs. The universities of California, Illinois and the University of Minnesota are pioneers in the subject (Ashbrook \& Reinhardt, 1985). However, as of 2010, it has been estimated that more than 140 higher education institutions practice environmental policies (Demaman, Funk, Hepp, Adário, \& Pergher, 2004; Sassiotto, 2005; Tavares \& Bendassolli, 2005, Araújo \& Viana, 2012). About ten of these institutions are International Organization for Standardization, ISO 14001, certified (ISO, 2004), being a worldwide example the University of the United Nations located in Tokyo, Japan (Delgado, 2005). Another highlight is the University of Vale do Rio dos Sinos (Unisinos) located in the city of São Leopoldo, Rio Grande do Sul (Conto, 2012).

The system based on ISO 14001 is one of the most widely adopted environmental management models in the world. It is a certification in the form of requirements that requires procedures and initiatives, without defining how they should be carried out, besides demanding that local environmental legislation be obeyed (Oliveira \& Pinheiro, 2010; ISO, 2004).

In the academic environment, the implementation of the ISO 14001 standard is the possibility of standardization of the routines and procedures required for a university to be environmentally certified, complying with international standards. The local legislation in force is not replaced, but reinforced due to the requirements in its full compliance for certification to be granted (Oliveira \& Pinheiro, 2010; Brazil, 1997).

Corroborating with the idea of implementing an EMS and verifying that in the academic world there is the possibility of its implementation with success cases, this work presents analysis of the economic viability in the implementation of the chemical waste management system in teaching and research laboratories.

\section{Methodology}

The study was developed with 13 technicians from laboratories of the teaching, research and clinical of the Universidade do Sagrado Coração, a University in the city of Bauru - SP, Brazil in steps.

Step 1 - It was applied the questionnaire (attached) with the objective of identifying the chemical waste generators of the university and also of qualifying and quantifying the generated waste.

Step 2 - With the results of the questionnaires, the data was tabulated. In addition, a study was carried out to 
verify if it would be feasible for universities in the interior of the state of São Paulo: to establish a laboratory to treat them at the university, to adapt a chemistry laboratory already University or send the waste to be treated and discarded by outsourced companies.

Step 3 - Survey of costs involved and calculation of financial viability for the management of chemical residues at a university.

\subsection{Economic Aspects}

The evaluation of the financial viability of a project, whether in the EMS involves obtaining results according to goals estimated by the organization. The decisions to be made must be in accordance with investments, financing, and distribution of results. Decisions must go through financial planning, which involves the analyzes between funding and investment available in a given organization. The consequences of decisions will depend on the scenarios and impacts of feasibility linked to the expected results (Rêgo-Bordeaux, Paulo, Spritzer, \& Zoyes, 2010; Gitman, 2010; Neto, 2003).

The most commonly used method for analyzing investments is discounted cash flow. It depends on the projection of the flows, estimates of residual value and the determination of the discount rate. It is divided into initial investment and in the project operations phase, which generates the cash flows. In the cash flow, the resource flows are indicated, with their outputs (negative value) or inputs (positive value) (Rêgo-Bordaux et al., 2010; Gitman, 2010).

Cash flows are allocated in a given time, which is linked to the project's useful life or economic life. The evaluation of the opportunity cost and minimum rate of attractiveness are also involved in the elaboration of cash flows of a given enterprise, these components of the capital flow. The flow of capital can be divided into four parts: initial investment, operational cash flows, residual cash flow and the perpetuity of the project (Rêgo-Bordaux et al., 2010).

The decision on the execution of a given project requires a technical evaluation, which involves the simulation of the investment according to models, such as simple payback, discounted payback, Net Present Value (NPV), Internal Rate of Return (IRR) and Profitability Index (PI) (Razeira \& Pereira, 2013; Rêgo-Bordaux et al., 2010; Graham \& Harvey, 2001).

The simple payback model involves the invested capital return time and is the most used method for evaluating a project, where a maximum investment recovery period is established, which will be used to analyze the feasibility of the project. In this case, the investment amounts and the sum of the cash flows must be equal to the initial investment. In the same way, taking into account the attractiveness, discount and interest rates, one can implement the model by discounted payback. These two methods can be very useful for evaluating projects of low financial significance (Rêgo-Bordaux et al., 2010; Gitman, 2010; Razeira \& Pereira, 2013).

The valuation of NPV is a function of four variables: value invested, value of cash flow generated, when cash flow should occur and what the associated risk. The NPV method takes into account the initial investment, the net cash flow at a given date, the cost of capital defined by the institution and the residual value of the project at the end of the analysis period. The NPV relates the four variables through the calculation, where the initial investment is discounted from the present value of the expected cash flow. The investment decision is made as follows:

A) NPV $>0$ - feasible project;

B) $\mathrm{NPV}=0$ - accept or not;

C) NPV $<0$ - non-feasible design.

Having a positive NPV the project being analyzed will have all of its investment recovered, the investment remuneration is higher than the attractiveness rate and the project will generate a wealth gain, represented by NPV.

The IRR is a method that competes with the analysis via NPV, since it summarizes all the merits of the project in a single number. The IRR is a reference to define the acceptance or not of a project, either in the implementation of an EMS or another project.

A) cost of capital $<$ IRR - accept the project (NPV $>0$ );

B) cost of capital $=$ IRR - accept or not $(\mathrm{NPV}=0)$;

C) cost of capital $>$ IRR - rejected project $(\mathrm{NPV}<0)$.

The major advantage of using the IRR method is the ability to relate the interest rate (result) to the cost of capital. 
This decision is the most used by the financial area. The method by the PI is a relation between the present value of the cash received and the initial investment. Thus, we have:
A) PI > 1 - investment will be recovered, with increased wealth;
B) $\mathrm{PI}=1$ - investment remunerated exactly at the required rate;
C) $\mathrm{PI}<1$ - investment not recovered.

Research carried out indicated that about $78 \%$ of the financial executives of the 392 largest US companies prefer to use NPV and IRR for decision making, followed by simple payback with 55\% (Markovics, 2016; Kengatharan, 2016).

\section{Results and Discussion}

The results obtained by the analysis of the questionnaire showed that the university generates chemical residues in the following laboratories: Anatomy, Biology, Design, Engineering, Aesthetics, Photography, Herbarium, Clinical Analysis Laboratory, Dentistry, Chemistry, Sugar and Alcohol.

Other information obtained through the application of the questionnaire are described in Table 1.

Table 1. Information on laboratories generating chemical residues

\begin{tabular}{ll}
\hline Questão & Respostas \\
\hline 1) What kind of chemicals are used in & Acids (21.74\%), Bases (21.74\%), Organic Solvents (13.04\%), Solid \\
this laboratory? & Metals (8.69\%), Dyes (8.69\%), Halogenates Metals (4.34\%), \\
& Non-Halogenated (4.34\%), Oxides (4.34\%), Salts (4.34\%) and \\
& Others (4.34\%). \\
\hline 2) Are there chemicals out of date? & Yes (20\%) \\
& No (80\%) \\
\hline
\end{tabular}

3) The chemical residues in this Experiments, in the areas of research, teaching and attendance to the laboratory, are generated from which population (Dentistry). process?
4) What is the classification of the waste generated, according to its hazard?

\section{Not Dangerous (66.66\%)}

Dangerous Inert (33.33\%)

Dangerous not Inert $(0.00 \%)$
5) What procedure is being adopted by the laboratory at the time of disposal of chemical residues?
Saved, as collection is not being performed $(20 \%)$

Others: Outsourced collection is being done ( $80 \%)$

6) Where is this chemical waste being Store in a room (80\%) stored? Who is responsible for this site?

Store in a suitable container $(20 \%)$

7) If it is being collected, how long is it 1 week (80\%) being stored until collection?

Other: not being collected (20\%)

8) How are these wastes stored? Plastic bottles (60\%)

Glass jars (20\%)

Sacks $(20 \%)$

9) What is the volume of waste
generated in your laboratory until
disposal?

10) What is the labeling method used for the chemical residues generated in this laboratory?

11) Have you encountered any difficulties in properly disposing of the chemical residues generated in this laboratory?
1 Liter to 5 Liters $(60 \%)$

Above 20 Liters (20\%)

Solid mass: $80 \mathrm{Kg} /$ week (20\%)

Written permanent pen in the bottle in all laboratories interviewed $(100 \%)$

There are only two laboratories that are encountering problems with waste collection due to lack of bottles for proper storage 
Using the information in Table 1, the financial analysis was carried out for the construction and implementation of a waste laboratory, which is presented in Table 2.

Table 2. Cost of construction and implantation of a waste laboratory

\begin{tabular}{lc}
\hline \multicolumn{1}{c}{ ITEM } & TOTAL PRICE (U\$) \\
\hline Construction - Laboratory for Treatment of Chemical Waste $\left(60 \mathrm{~m}^{2}\right)$ & $61,884.84$ \\
Construction - Shelter for Chemical Waste $\left(20 \mathrm{~m}^{2}\right)$ & $8,840.70$ \\
Equipments & $12,186.37$ \\
Furniture and e Tables & $14,953.60$ \\
\hline \multicolumn{1}{c}{ Total Investiment } & $\mathbf{9 7 , 8 6 5 . 5 1}$ \\
\hline
\end{tabular}

A second alternative was to adapt an existing structure, in this case the chemistry laboratory, in its idle period. Only the purchase of the necessary equipment for the treatment of chemical residues was considered for the calculation. Their values are detailed in Table 2.

Table 3. Cust of the equipaments

\begin{tabular}{cc}
\hline ITEM & TOTAL PRICE (U\$) \\
\hline Equipaments & $12,132.69$ \\
\hline Total of the investiments & $\mathbf{1 2 , 1 3 2 . 6 9}$ \\
\hline
\end{tabular}

The cost of the waste collection and treatment service was budgeted at three specialized outsourced companies and thus stipulated lower value for calculation. For collection would be charged $\$ 15.96$ and per liter $\$ 1.33$. Monthly it spends about $\$ 251,28$, annually, the cost reaches U $\$ 3,015.42$ with the outsourcing.

Based on the concepts adopted in the financial analysis, the cash flow and exit were raised, where the NPV, the IRR and the project payback were found.

Inflation was also included in the calculation. Since this index has reached values close to $10 \%$ at the present time, this value was adopted for the first year and it was estimated that the national index gradually reduces over the years, with expectations of equilibrium of the national economy, being the minimum adopted of $6.5 \%$.

It was defined the value of the Minimum Attractive Rate (MAR) and that this would be changed according to the inflation, therefore its value is composed of the percentage of inflation of the year plus $5 \%$ of business risk.

In year zero, in the columns: Cash Flow, Accumulated Cash Flow, Discounted Cash Flow and Accumulated Discounted Cash Flow, present the value of the initial investment made by the university in the project alternative.

In the Cash Flow column, the values of output (investment) and inputs (financial returns) in the project are represented. In order to establish the values in this column, during the ten years of the project, the annual inflation rate was added to the inflation index of the previous year. This action was taken to keep the value updated each year. In the Discounted Cash Flow, the value was updated according to the formula of NPV being applied to the variable MAR according to the respective year.

In the Accumulated Cash Flow and Accumulated Discounted Cash Flow columns, the sums of each annual amount are being made in order to obtain the cash value at the end of the ten years, so that it can be checked whether it has been closed at a loss or obtained financial feedback.

The results (Table 4) indicate the impossibility of constructing a laboratory to treat the chemical residues, because, during a ten year period, it was not possible to obtain a return on invested capital, as can be seen in the final and discounted cash flows. In addition, since cash flows did not show a financial return, it was not possible to calculate the time of return, simple payback and discounted payback. The NPV and IRR values were both negative of U\$76.479,29 and $11.97 \%$, respectively. 
Table 4. Calculation of financial viability for the construction of a waste laboratory

\begin{tabular}{ccccccc}
\hline Year & $\begin{array}{c}\text { Inflation } \\
\text { Projection }\end{array}$ & $\begin{array}{c}\text { MAR } \\
\text { (Inflation }+5 \% \\
\text { of the risk) }\end{array}$ & $\begin{array}{c}\text { Cash Flow } \\
(\mathrm{U} \$)\end{array}$ & $\begin{array}{c}\text { Cash Flow } \\
\text { accumulated (U\$) }\end{array}$ & $\begin{array}{c}\text { Cash Flow } \\
\text { discounted } \\
(\mathrm{U} \$)\end{array}$ & $\begin{array}{c}\text { Cash Flow } \\
\text { discounted } \\
\text { accumulated (U\$) }\end{array}$ \\
\hline 0 & - & - & $\$-98,857.77$ & $\$-98,857.77$ & $\$-98,857.77$ & $\$-98,857.77$ \\
1 & $10,0 \%$ & $15,0 \%$ & $\$ 3,052.12$ & $\$-95,805.65$ & $\$ 2,654.02$ & $\$-96,203.75$ \\
2 & $8,0 \%$ & $13,0 \%$ & $\$ 3,357.34$ & $\$-92,448.31$ & $\$ 2,583.56$ & $\$-93,620.19$ \\
3 & $6,7 \%$ & $11,7 \%$ & $\$ 3,625.92$ & $\$-88 ., 22.38$ & $\$ 2,497.98$ & $\$ 91,122.21$ \\
4 & $6,5 \%$ & $11,5 \%$ & $\$ 3,868.86$ & $\$-84,953.52$ & $\$ 2,390.45$ & $\$-88,731.76$ \\
5 & $6,5 \%$ & $11,5 \%$ & $\$ 4,120.34$ & $\$-80,833.19$ & $\$ 2,283.25$ & $\$-86,448.51$ \\
6 & $6,5 \%$ & $11,5 \%$ & $\$ 4,388.16$ & $\$-76,445.03$ & $\$ 2,180.86$ & $\$-84,267.65$ \\
7 & $6,5 \%$ & $11,5 \%$ & $\$ 4,673.39$ & $\$-71,771.64$ & $\$ 2,083.06$ & $\$-82,184.58$ \\
8 & $6,5 \%$ & $11,5 \%$ & $\$ 4,977.16$ & $\$-66,794.48$ & $\$ 1,989.66$ & $\$-80,194.93$ \\
9 & $6,5 \%$ & $11,5 \%$ & $\$ 5,300.68$ & $\$-61,493.80$ & $\$ 1,900.43$ & $\$-78,294.49$ \\
10 & $6,5 \%$ & $11,5 \%$ & $\$ 5,645.22$ & $\$-55,848.58$ & $\$ 1,815.21$ & $\$-76,479.28$ \\
\hline
\end{tabular}

$M A R=$ Inflation $+5 \%$ of the risk

$$
\begin{aligned}
& \text { NPV }(\$ 76,479.28) \\
& \text { IRR }(11,97 \%)
\end{aligned}
$$

\begin{tabular}{|c|c|c|c|c|c|c|}
\hline Year & $\begin{array}{l}\text { Inflation } \\
\text { Projection }\end{array}$ & $\begin{array}{c}\text { MAR } \\
\text { (Inflation }+ \\
5 \% \text { of the } \\
\text { risk) }\end{array}$ & $\begin{array}{l}\text { Cash Flow } \\
\text { (U\$) }\end{array}$ & $\begin{array}{l}\text { Cash Flow } \\
\text { accumulated } \\
\text { (U\$) }\end{array}$ & $\begin{array}{l}\text { Cash Flow } \\
\text { discounted } \\
\text { (U\$) }\end{array}$ & $\begin{array}{c}\text { Cash Flow } \\
\text { discounted } \\
\text { accumulated } \\
\text { (U\$) }\end{array}$ \\
\hline 0 & - & - & $\$(12,132.69)$ & $\$(12,132.69)$ & $\$(12,132.69)$ & $\$(12,132.69)$ \\
\hline 1 & $10,0 \%$ & $15,0 \%$ & $\$ 3,052.12$ & $\$(9,080.56)$ & $2,654.02$ & $\$ 9,478.67$ \\
\hline 2 & $8,0 \%$ & $13,0 \%$ & $\$ 3,357.34$ & $\$(5,723.23)$ & $2,583.56$ & $\$ 9,478.67$ \\
\hline 3 & $6,7 \%$ & $11,7 \%$ & $\$ 3,625.92$ & $\$(2,097.30)$ & $2,497.98$ & $\$ 4.397 .13$ \\
\hline 4 & $6,5 \%$ & $11,5 \%$ & $\$ 3,868.86$ & $\$ 1,771.56$ & $2,390.45$ & $\$ 2.006 .68$ \\
\hline 5 & $6,5 \%$ & $11,5 \%$ & $\$ 4,120.34$ & $\$ 5,891.90$ & $2,283.25$ & \$ 276.57 \\
\hline 6 & $6,5 \%$ & $11,5 \%$ & $\$ 4,388.16$ & $\$ 10,280.05$ & $2,180.86$ & $\$ 2,457.43$ \\
\hline 7 & $6,5 \%$ & $11,5 \%$ & $\$ 4,673.39$ & $\$ 14,953.44$ & $2,083.06$ & $\$ 4,540.50$ \\
\hline 8 & $6,5 \%$ & $11,5 \%$ & $\$ 4,977.16$ & $\$ 19,930.60$ & $1,989.66$ & $\$ 6,530.15$ \\
\hline 9 & $6,5 \%$ & $11,5 \%$ & $\$ 5,300.68$ & $\$ 25,231.28$ & $1,900.43$ & $\$ 8,430.59$ \\
\hline 10 & $6,5 \%$ & $11,5 \%$ & $\$ 18,877.05$ & $\$ 30,876.50$ & $1,815.21$ & $\$ 10,245.80$ \\
\hline \multicolumn{7}{|c|}{$M A R=I N F L A T I O N+5 \%$ RISK } \\
\hline \multicolumn{7}{|c|}{ NPV $\$ 10,245.80$} \\
\hline \multicolumn{7}{|c|}{ IRR $28,62 \%$} \\
\hline \multicolumn{3}{|c|}{$P A Y B A C K$ SIMPLE } & Year: 3 & Month: 6 & \multicolumn{2}{|l|}{ Day: 15} \\
\hline & \multicolumn{2}{|c|}{ PAYBACK DISCOUTED } & Year: 4 & Month: 10 & \multicolumn{2}{|l|}{ Day: 16} \\
\hline
\end{tabular}

Table 5. Calculation of financial viability for laboratory adaptation 
In the second investment alternative, the proposal was to adapt the structure of the existing laboratory, in this case, the Chemistry Laboratory, and use it in the periods of idleness, using the already existing workforce. To adapt it would only require the acquisition of equipment, as the laboratory includes the structure and shelter for waste, as well as benches and furniture. In Table 5, the results are found through the calculations of NPV, IRR and payback.

The results of the second alternative indicate the feasibility of adapting the existing laboratory to treat the waste, since the NPV was $\$ 10,122.593$, the IRR of $28.62 \%$, the simple payback period of 3 years, 6 months and 15 days and the discounted payback of 4 years, 10 months and 16 days.

Thus, it is concluded that adapting the existing structure is more financially viable and that after the four year period, according to the calculation of the discounted payback it is possible to obtain the financial return.

However, this is a specific condition for the case studied, and it is now found that the percentage of universities that have a laboratory for the treatment and use of their waste is extremely low. It is also necessary to take into account the need for environmental awareness on the part of the stakeholders who prefer to transfer the management of laboratory waste to outsourced companies, if it is burdened with any problem regarding the final destination of the same.

\section{Conclusions}

After a bibliographical survey and data collection, we noticed that the subject is still insipient in the academic environment, and that the examples found, for the most part were from other countries.

Also according to the bibliography, most Brazilian Universities that adopt an EMS of their residues have incorporated quality systems that audit environmental factors, such as ISO (International Standardization for Optimization).

From the answers found by the respondents, we also noticed the degree of dangerousness of the waste generated as well as the products handled in our laboratories. Which makes us question whether the outsourced companies would have expertise to treat such waste.

We also conclude that there is an urgent need for an EMS to control the generation of waste from the University, where we should already have a Solid Waste Management Plan.

The financial figures presented are relatively small if we consider that the legislation itself determines a greater control and a specific workforce for this type of treatment.

Because the EMS is insipient in universities, and the lab's idleness over time, we can also think that the University of the Sacred Heart could not only solve the problem of its waste management, but also sell the treatment services to other Universities. This would drastically reduce the cost of investment in the long term, reducing the rate of return on investment, since the university itself has professionals capable of managing this service and could even be a field of experimentation for undergraduate and postgraduate courses.

This study shows the importance of the technical-financial analysis of a project even in the academic world, before making a decision. Financial management provides strategic benefits to the organization, whether in the corporate or academic setting, providing inputs for decision making. The construction of the financial analysis presented in this paper can serve as a model and stimulus for other university units.

\section{References}

Araújo, R. S., \& Viana, E. (2012). Diagnosis of solid waste generated in the school of arts, sciences and humanities as an instrument for the preparation of a management plan in the unit. Journal of Management, Education and Environmental Technology, 8(8), 1805-1817. http://dx.doi.org/10.5902/223611707231

Ashbrook, P. C., \& Reinhardt, P. A. (1985.) Hazardous wastes in academia. Environmetal Science \& Technology, 19(2), 1150-1155.

Brazil. (1997). Conama Resolution No. 237: Provides for the revision and complementation of procedures and criteria used for environmental licensing. Retrieved from http://www.mma.gov.br/port/conama/res/res97/res23797.html

Brazil. (1998). Law No. 9,605: Provides for criminal and administrative sanctions derived from conducts and activities harmful to the environment, and other measures. Retrieved from http://www.planalto.gov.br/ccivil_03/leis/L9605.htm.

Brazil. (2010). Law No. 12.305: Establishes the National Solid Waste Policy. Retrieved from http://www.planalto.gov.br/ccivil_03/_ato2007-2010/2010/lei/112305.htm 
Conto, S. M. (2012). Resenha: Gestão de resíduos em universidades. Rosa dos Ventos - Turismo e Hospitalidade, $4(1), 110-113$.

Cunha, C. J. (2001). The laboratory waste management program of the chemistry department of UFPR. Quimica Nova, 24(3), 424-427.

Delgado, C. C. (2005). Propuesta de implementación de un Sistema de gestión ambiental para campus universitario. Poliantea, 2(3), 21-43.

Demaman, A. S., Funk, S., Hepp, L. H., Adário, A. M. dos S., \& Pergher, S. B. C. (2004). A program for managing residues from teaching laboratories of the integrated regional University of alto Uruguai e das Missões - Campus Erechim. Química Nova, 27(4), 674-677. http://dx.doi.org/10.1590/S0100-40422004000400026

Dionizio, A. S. (2013). Qualitative and quantitative survey of hazardous waste as instruments for the elaboration of a management plan at the Faculty of Dentistry of Bauru (FOB-USP) (Unpublished). Universidade do Sagrado Coração, Bauru, Brazil.

Faria, B. de A., Oliveira, S. M. de, \& Santos, A. de P. (2010). Waste treatment practices lecture in chemistry. Enciclopédia Biosfera, 6(10), 1-7.

Furiam, S. M., \& Güinther, W. R. (2006). Assement of the environmental education on solid waste management in Feira de Santana state university campus. Sitientibus, Feira de Santana, 35, 7-27.

Giloni-Lima, P. C., \& Lima, V. A. (2008). Integrated management for chemical residues in academic institutions. Química Nova, 31(6), 1595-1598. http://dx.doi.org/10.1590/S0100-40422008000600053

Gitman, L. J. (2010). Principles of managerial finance (10th ed.). New York, NY: Pearson.

Gouveia, N. (2012). Solid urban waste: socio-environmental impacts and prospects for sustainable management

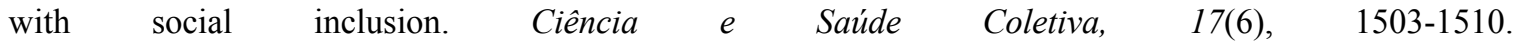
http://dx.doi.org/10.1590/S1413-81232012000600014

Graham, J. R., \& Harvey, C. R. (2001). The theory and practice of corporate finance: evidence from the field. Journal of Financial Economics, 60(2-3), 187-243. http://dx.doi.org/10.1016/S0304-405X(01)00044-7

International Organization for Standardization. ISO 14001. (2004). Environmental management systemsRequirements with guidance for use. Genebra, 23p.

Jacobi, P. R., \& Besen, G. R. (2006). Solid waste management in the Metropolitan Region of São Paulo advances and challenges. São Paulo em Perspectiva, 20(2), 90-104.

Jacobi, P. R., \& Besen, G. R. (2011). Solid Waste Management in São Paulo: The challenges of sustainability Estudos Avançados, 25(71), 135-158. http://dx.doi.org/10.1590/S0103-40142011000100010

Kengatharan, L. (2016). Capital Budgeting Theory and Practice: A Review and Agenda for Future Research. Applied Economics and Finance, 3(2), 15-38. http://dx.doi.org/10.11114/aef.v3i2.1261

Markovics, K. S. (2016). Capital budgeting methods used in some European countries and in the United States. Universal Journal of Management, 4(6), 348-360. http://doi.org/10.13189/ujm.2016.040604

Neto, A. A. (2003). Finanças Corporativas e Valor. São Paulo, SP: Atlas.

Nolasco, F. R., Tavares, G. A., \& Bendassoli, J. A. (2006). Establishment of laboratory waste management programs in universities: critical review and recommendations. Engenharia Sanitária e Ambiental, 11(2), 118-124. http://dx.doi.org/10.1590/S1413-41522006000200004.

Oliveira, O. J., \& Pinheiro, C. R. M. S. (2010). Implantation of environmental management systems ISO 14001: a contribution of the personnel management area. Gestão \& Produção, 17(1), 51-61. http://dx.doi.org/10.1590/S0104-530X2010000100005

Razeira, R. M., \& Pereira, T. da C. (2013). Critical analysis of the physical and financial planning of a residential complex located in the mainland of Florianópolis. Federal University of Santa Catarina, Florianópolis, Brazil. Retrieved from https://repositorio.ufsc.br/bitstream/handle/123456789/115448/TCC_2_20132.pdf?sequence=1

Rêgo-Bordeaux, R., Paulo, G. P., Spritzer, I. M. P. A., \& Zoyes, L. P. (2010). Viabilidade Econômico-financeira de Projetos (3rd ed.). Rio de Janeiro, RJ: FGV Publishing House.

São Paulo. (2006). Law No. 12,300: Establishes the State Policy on Solid Waste and defines principles and 
guidelines. Retrieved from http://www.legislacao.sp.gov.br.

Sassiotto, M. L. P. (2005). Waste management of chemical laboratories in universities - case study of the department of chemistry at UFSCar. (Unpublished master's thesis). Federal University of São Carlos, São Carlos, Brazil.

Tauchen, J., \& Brandli, L. L. (2006) Environmental management in higher-education institutions: a model for implementation at a university campi. Management \& Production, 13(3), 503-515. http://dx.doi.org/10.1590/S0104-530X2006000300012

Tavares, G. A., \& Bendassolli, J. A. (2005). Establishment of a management program for chemical residues and waste water, generated in laboratories of the centro de energia nuclear na agricultura (CENA/USP). Química Nova, 28(4), 732-738. http://dx.doi.org/10.1590/S0100-40422005000400031 


\section{Appendix A}

UNIVERSIDADE DO REGER -

SAGRADO REDUCÃO DA

CORAÇĀO GERAÇÃO DE RESÍDUOS

\section{QUESTIONNARIE CHEMICAL WASTES}

\section{Local:}

Date:

Technical Manager:

1) This place is used as (can be more of an alternative):

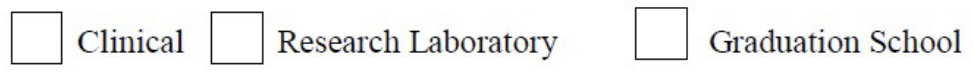

2) In this place there is practice regarding the disposal of chemical residues of:

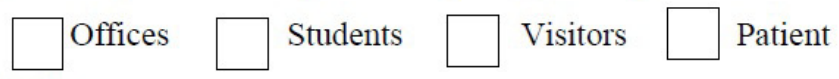

Justifiy:

3) How is waste disposal done at this location? (Consider: storage, identification, separation and destination).

4) Would you reuse treated waste if it was recovered on campus?

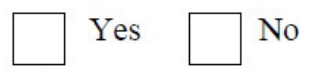

Justifiy:

5) Do you find it interesting that the campus has a chemical waste laboratory? Because?

6) Among the items below, what and how much is generated as waste at this location?

\begin{tabular}{|l|l|l|}
\hline & \multicolumn{1}{|c|}{ Wastes } & Quantity \\
\hline & Acids & \\
\hline & Bases & \\
\hline & Organic Solvents & \\
\hline & Solid Metals & \\
\hline & Dyes & \\
\hline & Halogenates Meta & \\
\hline & Non-Halogenated & \\
\hline & Oxides & \\
\hline & Salts & \\
\hline & Others (specify) & \\
\hline
\end{tabular}

7) What, in your opinion, would be necessary for this site to actively participate in waste management?

\section{Copyrights}

Copyright for this article is retained by the author(s), with first publication rights granted to the journal.

This is an open-access article distributed under the terms and conditions of the Creative Commons Attribution license (http://creativecommons.org/licenses/by/4.0/). 